\title{
Principals in the role of Sisyphus: School leadership in challenging times
}

\begin{abstract}
This study seeks to address the main difficulties encountered by principals when carrying out their leadership role. A total of 100 principals from infant, primary and secondary schools in the province of Alicante (Spain) were interviewed. The results show that the respondents were more affected by external problems and difficulties inherent to their role than by their personal limitations and the impact leadership has on their lives. All the difficulties identified reveal that the prevailing leadership model continues to be managerial and individualist in character, and the paper puts forward a number of proposals on how this might be changed.
\end{abstract}

Keywords: educational leadership; leadership weaknesses; leadership models; personal cost of leadership.

\section{Introduction}

For some years there has been a marked decline in the number of candidates applying for the post of school principal in countries such as the UK, Australia and New Zealand (Harris and Jones, 2017; Reames, Kochan and Zhu, 2014). The problem came to light in England over a decade ago when proposals were put forward to encourage teachers to aspire to the position (Bush, 2015). It may have been a consequence of various studies that had found that three-quarters of English and Welsh primary school teachers who were eligible for principalship had no intention of applying for the position (MacBeath, 2011). In the US, too, research has been suggesting for several years that there is a critical shortage of quality candidates for the post of principal (De Jong, Grundmeyer and Yankey, 2017). Markow, Macia and Lee (2013), for instance, showed that most teachers (69\%) said they were not interested in the principal's job. The same situation has been found in Spain, where almost 50\% of schools are unable to attract candidates for the post and vacancies have to be filled by individuals appointed by the Local Education Authority (LEA) (Aramendi, Teixidó and Bernal, 2010; Pont, Nusche and Moorman, 2008). 
This lack of candidates is associated with school leadership becoming less attractive, an explanation supported by the high numbers of people leaving the profession. The study by Campbell, DeArmond and Denice (2014), for example, found that around one in five school principals in the state of Washington leave the position each year. Meanwhile Béteille, Kalogrides and Loeb (2011) show that annually the same number leave their jobs in the fourth largest public school district in the US (Miami-Dade County), resulting in lower teacher retention and lower student achievement. Possible reasons for this were divided into two categories by the Educational Research Service (2000) for the National Association of Elementary School Principals: the nature of the job and external influences. Thomson (2008) and Tucker (2010) associate the post with high levels of stress, while Markow et al. (2013) report that three-quarters of principals say their job has become highly complex, with almost half admitting that they suffered a great deal of stress on various days of the week. In fact Darmody and Smyth (2014) found that 70\% of principals had experienced work-related stress.

A significant stressor comes in the shape of demands by the LEA, especially during periods of education reform, for schools to achieve better academic results. This has been shown to be the second biggest factor affecting principals, after the impact of teachers' actions (Gu and Johanson, 2013; May and Supovitz, 2011). Similarly, some authors (Darmody and Smyth, 2014; Doyle and Locke, 2014; Drago and Pecchia, 2016) have pointed to additional sources of stress, such as the multiple demands placed on the leaders' time to complete their tasks in a balanced way, the levels of isolation experienced, the increasing number of environments that involve pressures due to social problems and disadvantaged students, etc. Others (De Jong et al., 2017; Wells, Maxfield and Klocko, 2011) cite the toll the job takes on family and personal life - for Reames et al. (2014) this is one of the main reasons for leaving the post - and the relatively low pay, bearing in mind the considerable increase in responsibility and duties in some countries. Along with the lack of government support, all these have become determining factors contributing to the post's lack of appeal and low job satisfaction among principals, as shown in studies such as Markow et al. (2013).

Some investigations have particularly noted the contextual nature of the reasons teachers give for not applying for the post and argue that new educational scenarios generate dilemmas, resistance and 
imbalances that pose enormous difficulties for leadership (Barty, Thompson, Blackmore and Sachs, 2005; Harris and Jones, 2017). This could mean that the lack of candidates for leadership posts and the high turnover in some countries are due not so much to the loss of a transformative vision on the part of education professionals, but rather to the existence of external variables that influence that vision.

\section{Leadership models as a theoretical framework for understanding the difficulties faced}

A number of studies have been conducted with the aim of ranking leadership models (Bush and Glover, 2014; Robinson, 2010). Analysing these makes it possible to see the position of these models on the continuum. At one end we find the managerial, individualist models that seek to preserve the institution and lack any inspired vision. These would be identified as being the traditional view of leadership because the notion of the superprincipal, carrying all the responsibility and the entire workload, is no longer appropriate in most education contexts today (Döös, Wilhelmson, Madestam and Örnberg, 2017). At the other end of the continuum we find models where leadership is a role distributed among community members, which would be associated with a more up-to-date view. This distinction in the classification of models depends on questions such as who exercises leadership, how goals are set and how the leader works to achieve them. The subject is dealt with in detail by Bush and Glover (2014), who classify a series of models on the basis of who exercises the leadership (individual v. shared leadership).

It has been shown that the adoption of one leadership model instead of another depends, among other things, on the requirements of the context (Bush and Glover, 2014; Hallinger, 2016). Yukl (2006) accounts for this idea by noting the existence of situational factors that affect all leadership, regardless of the principals' performance. Wohlstetter, Datnow and Park (2008) explain that the leaders' work and therefore the model adopted are conditioned by the policies applied to the town, district or region in which the school is located. Proof of this is the changes that have occurred since implementation of the National Curriculum and the Primary Strategies (Weindling and Dimmock, 2006), under the slogan Every Child Matters, and the No Child Left Behind Act (Evans, 2009) in the UK and the US respectively. Nevertheless, despite contextual conditioning it would appear that there is agreement 
today that the decision-making and pursuit of a vision of the school from the unipersonal perspective of the leader is not enough (Ulhøi and Müller, 2014). Indeed, on a practical level, some countries have already made the move from individual leadership to shared leadership (Crawford, 2012). The definitions of shared leadership provided by Pearce, Manz and Sims (2008) and Mhera, Smith, Dixon and Robertson (2006) enable us to identify it as a process of mutual influence between the members of an organization, who distribute the tasks and responsibilities among themselves with the aim of attaining a common vision they have of the school.

Bush and Glover (2014) place on this side of the scales four styles of leadership in vogue today. First, distributed leadership, which recognizes sources of leadership other than the principal, although this does not mean that everyone is a leader or that the principal ceases to be one (Harris, 2013). Second, leadership for learning can be understood as a more evolved model of instructional leadership because it focuses less on results and more on the teaching, concentrating on processes and learning (Hallinger and Heck, 2010). Third, teacher leadership is based on empowering teachers to improve how they do their job, how to be leaders in the classroom (Muijs and Harris, 2007). And fourth, system leadership can be defined as a type of leadership developed in a network of schools which work closely together in pursuit of shared aspirations and common goals, mainly in connection with improving student learning (Hopkins and Highman, 2007).

On the other side of the scales four other models can be identified. The first of these is managerial leadership, in which the leader's work is focused on preserving the system by ensuring the day-to-day functioning and organization of the school. Naturally this involves a serious concern for administrative matters, which precludes any visionary perspective on the part of the leader (Goddard, 2003). Second, instructional leadership, which revolves around the importance of promoting a climate conducive to teaching, where the teachers are given support and have the chance to participate in the school curriculum. Some authors (Robinson, Lloyd and Rowe, 2008; Wahlstrom, Louis, Leithwood and Anderson, 2010) define it as the effort to improve the teaching and learning processes through effective management, aimed at making the most of the opportunities offered by diversity, providing guidance for teachers and encouraging the organization of learning. Third, transformational leadership 
is based on the leader's ability to change the expectations, motivations and perceptions of the members of the organization, challenging the status quo and advocating the development of creativity among their followers (Bass and Riggio, 2006). And fourth, moral and authentic leadership, in which the leader's actions are determined by strong moral and ethical values and a strong sense of social justice (Day and Sammons, 2014).

It has been shown that shared leadership models have a positive impact on both the individual and the collective. As regards the latter, Wilhelmson and Döös (2016), for example, observe that shared leadership increases democratic practices and collaborative work in schools, impacting positively on academic results, while Döös et al. (2017) point out that it reduces the principal's workload and any feelings of solitude.

\section{Analysing difficulties as a way of better understanding school leadership: research questions}

Bearing these aspects in mind and with the aim of discovering the main difficulties involved in carrying out a leadership role in schools, this study analyses the problems experienced by a sample of principals using qualitative research methodology. The investigation was based on the following questions:

- Do the difficulties faced by the participating principals depend more on factors inherent to the leadership role or on external factors?

- What experiences are associated with the participants' perception of the difficulties they have to deal with when carrying out their work?

- What leadership models are characterized by the difficulties and weaknesses identified in the participants' discourses?

\section{Study design}

This study falls within the framework of the naturalistic research paradigm insofar as it focuses on exploring the difficulties faced by principals in their natural work settings (Lincoln and Guba, 1985). It is our aim to analyse these difficulties, identify their nature, study the impact they have on a personal level and assess the extent to which they reveal the leadership model that predominates in the 
context studied. From this methodological angle, an analysis of the content is then carried out, in the course of which the difficulties that the participants associate with the job are analysed in their professional context, since considering them outside this context would be meaningless (Cho and Lee, 2014).

\section{Context}

Since the figure of principal was first created in Spain in 1896 with the graduated schools model, it has undergone many changes in line with the country's ever-changing legislative measures affecting education. These changes have to a large degree affected principals' working conditions, their functions and other aspects such as selection processes and training. Depending on what period we consider, the selection process has been made more democratic or more technical-professional in character, the leadership model made more or less unilateral, the importance of previous training stressed or passed over, and the bureaucratic side of the principal's functions diminished or enhanced. On the basis of such a changeable legal evolution, the only certainty is that the Spanish principalship model has no clear identity.

The regulations governing today's model are set out in the Ley Orgánica para la Mejora de la Calidad Educativa (LOMCE, 2013 - The Improvement of Quality in Education Act). Applicants for the post of principal need to meet the following requirements: (1) a minimum of five years' experience in public education as a career civil servant, (2) a minimum of five years' teaching experience in public education in at least one of the teaching areas requested, (3) completion of a training course given by the relevant LEA or the Ministry of Education, and (4) submission of an action plan.

Both the LEA and the education community take part in the selection process, which is competitionbased and observes the principals of equality, advertising, merit and ability. Highly valued in candidates are prior experience in a school management team, their current service situation and position, and their having been given a positive assessment in the development of quality action plans. The LEA appoints principals for four-year periods, which it can extend for further four-year periods subject to positive assessment, although it can also impose a limit on the number of times a mandate can be renewed. 
Bearing in mind the above details along with what Rodríguez, García, García and Álvarez (2013, p.423) have to say on the subject, the principalship model in Spain is thus characterized by being quasi-elective and non-professional, having a time limit and offering the chance of a teaching career. As far as functions are concerned, there has traditionally been a common set of duties carried out by principals, and these fall into four general areas: (1) they represent the law and are responsible for compliance with it, (2) they coordinate activities, (3) they manage the school staff, and (4) they are responsible for approving the school's spending. Over the years a number of other tasks have been added, including liaising with the LEA, ensuring good relations in the school and organizing any necessary works and services. In addition, principals have gradually been assigned duties related to innovation, the development of internal and external assessments, and teacher empowerment. The most recent law governing education boosted their decision-making power to the detriment of the school council, giving them greater autonomy while increasing accountability. This increased autonomy allows them to take action for the purposes of improving educational provisions and methodology. They are now able to make small changes in human resources according to the requirements of the school, i.e. in certain circumstances. However, despite the fact that progress has been made, there is still a huge difference between what the law — and the international literature says and actual practice, which means that the bureaucratic, managerial model continues to prevail (Barrios-Arós et al., 2015; Bolívar, López and San Fabián, 2013).

\section{Participants}

The sample was made up of 100 principals from infant, primary and secondary schools in the province of Alicante (Spain), 38\% of whom were women and 62\% men, which is representative of the gender ratio in the area of school leadership in Spain. More than half (57\%) were over fifty years old. $68 \%$ had gained their experience as teachers in the course of careers spanning between twenty and thirty-five years, while only $18 \%$ had been principal for more than fifteen years.

$63 \%$ of the sample were in charge of infant and primary schools, while $37 \%$ were secondary school principals. A majority of the participating schools had between 401 and 600 students, although $2 \%$ had more than 1400. As regards staffing levels, almost 50\% had between 26 and 50 teachers. 
Three inspectors (two men and a woman) from the Alicante Education Inspection service recognized as experts with long professional careers - assisted us in the selection of the sample so as to ensure diversity and representativity. These inspectors were in charge of different districts, and this enabled us to gain access to principals from all over the province and make sure we had a wide variety of professionals working in different contexts within the same geographical framework. In addition, since Alicante is a bilingual area (Spanish and Valencian), this was acknowledged by the fact that two of the three inspectors were committed to promoting the teaching of the local language.

First of all, we met with the inspectors to explain the aim of the research. In this meeting it was agreed that we would select those principals considered as being representative of the role in the province of Alicante on the basis of their work, independently of the number of years they had been in the job. The inspectors sent emails to those they believed were ideal and accessible candidates for the study. The researchers then contacted these candidates by telephone to explain the aims of the study, assuring them that participation was voluntary and that any information obtained would be treated as confidential. Those who decided to participate - there was only one refusal - named a place and time for the interview to be carried out.

\section{Instruments used and data-collection process}

Semi-structured interviews were used for data collection. Since this study forms part of a much wider investigation into leadership in education, the final instrument (which was validated by three specialists in educational research) was composed of twelve open questions (see Annexe 1). All these were designed to gather information on five subject areas: (1) willingness to take on the job of principal, (2) professional identity, (3) professional development, (4) achievements and difficulties, and (5) needs and proposals. This particular study focuses on information pertaining to subject area four regarding difficulties. The study's research questions therefore also focus on difficulties, given that the aim is to analyse what the principals have to say on the subject. The national and international literature (Aramendi Teixidó and Bernal, 2010; Doyle and Locke, 2014; Drago and Pecchia, 2016) both note the growing difficulties encountered by principals in the exercise of their work, and hence the interest in recognizing what these difficulties are and identifying their nature and the leaderships 
models with which they may be associated. Hence also the reason for including an interview question that openly seeks to gather information relating to the obstacles that principals come across in their work.

All the interviews were carried out by the same researcher and were recorded with the participants' consent. The data collection process took place over a four-month period.

\section{Data analysis}

Once the interviews were transcribed, we designed an initial category and coding map on the basis of reading and rereading the participants' discourses. Conventional and direct content analyses were carried out (Hesieh and Shanon, 2005) following an inductive-deductive process, which was useful in adapting the analytical tool to interpretation. The inductive process, related to the nature of the difficulties and the principals' perception of them and their impact on a personal level, included open coding, the creation of categories and abstraction (Elo and Kyngäs, 2008). Meanwhile the deductive analysis involved the classification of leadership models as proposed by Bush and Glover (2014).

The information was coded using AQUAD 7 software (Huber and Gürtler, 2013), which significantly eased the tasks of organizing, summarizing and categorizing the information into units of meaning of varying breadth, i.e. categories and codes. Its internal logic makes it possible for researchers to conduct a rigorous analysis of the data to facilitate interpretation following a recursive process to match the categories and codes with the research questions.

The map of categories and codes was validated by three experts in educational research. The first draft was modified slightly during the coding process, since the information that was emerging called for the establishment of new codes which appear in the definitive framework (see Annexe 2).

During the analysis process the information was organized into two broad themes: (1) the nature of the difficulties, and (2) how they were perceived and the personal impact they had. Six codes emerged within the first theme, three of which involve the existence of internal difficulties as regards the schools and the principals' work itself, while the other three reflect the existence of external difficulties affecting the job. 
As for the second theme, which was also based on an inductive analysis of the information gathered, most of the participants' contributions concern the difficulties arising from the principals themselves, plus the personal cost involved in carrying out the work. This information is classified into just two codes: personal weaknesses/limitations and life consequences.

The narratives were identified using an alphanumeric system to ensure the participants' anonymity.

\section{Results}

An analysis of the principals' narratives showed there were two main themes: (1) the nature of the difficulties experienced, and (2) the personal cost of the difficulties and the principals' personal limitations. Analysing the first of these involved assessing the differences in the types of difficulty identified by the participants according to whether they were internal or external to the school. The second contained information about the personal limitations the leaders identified in the performance of their duties and their consequent impact on the individual and their family. There is a fairly close relationship between the two themes, since the impact of the difficulties characteristic of the second is a consequence of the obstacles identified in the first.

\section{Theme 1. Nature of the difficulties experienced}

This theme gathers together all the information referring to the types of difficulty experienced by participants according to whether they can be considered internal or external to the school. As can be seen in Table 1, which shows the relevant descriptive data, the range of obstacles identified is wide and varied.

The descriptive data are derived from the following calculations:

(1) The frequency $(F)$ is equal to the number of times the participants refer to an information unit or code.

(2) The frequency percentage (F\%) comes from the formula Fx100/Total F.

(3) The number of cases (C) is the number of principals who refer to a code.

(4) The presence percentage $(\mathrm{P} \%)$, i.e. the number of cases for each information unit as a proportion of the total, comes from the formula nCASESx100/totalCASES. 


\subsection{Internal school difficulties}

This section contains the participants' narratives involving difficulties inherent to performing their leadership role in schools.

\subsubsection{Task variety and complexity}

This code accounts for one of the highest percentages of cases $(\mathrm{C}(\%)=84)$ overall and also has a high frequency percentage $(\mathrm{F}(\%)=26.8)$. The information can be classified into four different aspects: (1) the wide range of tasks that principals are required to undertake, (2) the unpredictability of everyday school life, (3) the bureaucratic workload, and (4) the combination of teaching and principalship tasks. Table 2 provides a group of narratives representative of the different shades of meaning to be found under this code.

\section{[Insert Table 2 about here]}

The variety and complexity of the tasks are to some extent associated with the unpredictability of everyday school life. As can be seen from narratives $1 \mathrm{a}$ and $1 \mathrm{~b}$, the participating principals said they were responsible for many tasks that arise unexpectedly, as well as for the daily performance of their scheduled tasks. They are critical of the fact that jobs crop up unexpectedly (narratives $2 a$ and $2 b$ ) because this makes it difficult for them to plan their day. They also argue that the heavy load of administrative and bureaucratic tasks limits their ability and time to think about changes and pedagogical proposals. This is a cause of some frustration (3a and 3b). Finally, the last area identified refers to the difficulty in having to teach classes and perform a leadership role at the same time (4a and $4 b)$.

\subsubsection{Difficulties related to teaching staff}

This code was mentioned by $82 \%$ of participants, with a frequency of $19 \%$. It covers the difficulties that arise when being in charge of the teaching staff. From the range of information collected, the following aspects can be identified: (1) difficulties in coordinating teachers, (2) teachers' resistance to 
change, (3) composition of teaching staff, and (4) divisions among teaching staff. The narratives presented in Table 3 illustrate these aspects.

\section{[Insert Table 3 about here]}

The common denominator in all the accounts is the difficulty involved in being a leader of teachers (examples 1a and 1b). The reasons given were varied, but one of the most frequent references, especially relevant as regards public schools, concerned the difficulties involved in motivating the teaching staff because in general terms they are settled and secure in their jobs ( $2 a$ and $2 b$ ).

In addition, it can be seen from narratives $3 \mathrm{a}$ and $3 \mathrm{~b}$ that principals do not have the autonomy to choose teaching staff. The LEA is in charge of this task, which it carries out via an open call for applications. Participants said the random selection of teachers makes it difficult to manage them because they are unable to choose those with a particular profile. The interviewees also mentioned divisions between staff members as a result of political differences or different preferences in educational models (4a and $4 b)$.

\subsubsection{Difficulties related to students}

This code brings together any information relating to problems that may arise in schools as a result of interaction with and among students. 34\% of participating principals mentioned this, accounting for a frequency of $5.2 \%$. The data are organized according to the following aspects: (1) discipline and conflicts, and (2) working in problematic educational contexts involving the social, emotional and economic hardships faced by some students. The narratives in Table 4 show the difference between the two.

\section{[Insert Table 4 about here]}

As example 1a shows, one of the principals' concerns and a difficulty to be faced is the lack of discipline. Participants also refer to the problems of bullying and cyberbullying, as reflected in example $1 b$.

In addition they explain that the context itself can give rise to problem situations. As made clear in narratives $2 a$ and $2 b$, the contexts involving most vulnerability concern the needs of certain students 
that go beyond the academic sphere. Excerpt 2c, for instance, indicates that principals have to deal with the lack of affection that some children suffer in the family context.

\subsection{External and community-related difficulties}

This category covers the external obstacles identified by the participants. The data refer to variables that are independent of the principals' performance and are therefore beyond their control.

\subsubsection{Difficulties related to the Local Education Authority}

This code accounts for the highest frequency percentage and the highest proportion of cases in the study $(\mathrm{F}(\%)=37 ; \mathrm{C}(\%)=90)$. The data analysis enabled us to identify the following aspects: $(1)$ poor management, (2) lack of reward and consideration, (3) constant legislative changes, (4) acting as intermediaries between the LEA and the school community, (5) great responsibility, and (6) low levels of autonomy. Examples for each of these are shown in Table 5.

[Insert Table 5 about here]

The interviewees talked about the LEA's ineffective management of resources (example 1a). They explained that many of the deadlines imposed are too short, a great deal is demanded of them, and no clear guidelines are provided by those in charge (1b). They argue that if the LEA really knew what it was doing, the procedures would be different (1c).

The participants also commented that the LEA undervalues them and that their remuneration is insufficient considering all the responsibility they shoulder and the increasingly complex job they do (examples $2 \mathrm{a}$ and $2 \mathrm{~b}$ ). The feeling is, therefore, that they are given hardly any support in the performance of their duties (2c).

Another common feeling is frustration as regards the fact that they have to act as the link between the LEA and the school community (3a). They admitted that there are times when their political ideals do not match the LEA's proposals or the decisions imposed on them. This generates a certain amount of conflict and personal dilemmas (3b).

Finally, the high degree of responsibility combined with the low level of autonomy makes the task doubly difficult. Paradoxically, although principals are responsible for virtually everything that 
happens in schools, they have only a limited amount of autonomy when it comes to making decisions and taking action (examples $4 \mathrm{a}$ and $4 \mathrm{~b}$ ). It is this that makes them feel like puppets, as illustrated by narrative $4 \mathrm{c}$.

\subsubsection{Difficulties related to families}

About $36 \%$ of the principals, with a frequency percentage of $5.5 \%$, admitted that they had difficulties when dealing with families. The data show that the main targets for the principals' criticism are: (1) the demanding attitude of some parents, (2) the lack of support from parents, (3) increasingly permissive parenting styles, and (4) the parents' limited involvement and participation in school activities. Table 6 gives some example narratives illustrating these situations.

[Insert Table 6 about here]

Excerpt 1a highlights the fact that the passing of time has placed parents in a different position. They are now far more demanding and, instead of being on the side of the teaching staff, they seem to be against them. This is exemplified in narrative $2 \mathrm{a}$. Such behaviour is associated with much more permissive parenting styles (3a), in which the absence of defined limits can lead to problems of indiscipline and a lack of respect for the teachers. Finally, we see the difficulty involved in expecting parents to participate in school activities. In particular, as illustrated in excerpt $4 \mathrm{a}$, the principals stress the fact that the parents who most seldom visit the school are the very ones that they would be most interested in communicating with.

\subsubsection{Difficulties related to the community}

Relationships between the various sectors that make up the community have traditionally been noted for their complexity, and this aspect was mentioned by $39 \%$ of the participants with a frequency percentage of $6.6 \%$. Data on the subject can be split into two shades of meaning: (1) coexistence problems, and (2) context and curriculum.

[Insert Table 7 about here]

As we see in Table 7, narrative 1a reveals that different agents within the community go to the principal to solve their problems, and this can both multiply the amount of work to be done and lead 
to emotional overload. In this case in particular (excerpt $1 \mathrm{~b}$ ), achieving harmony between the different sectors is a complicated task. The principals also mentioned that some schools experience particular difficulties because of the complexity of their settings (2a) or the varied, wide-ranging academic pathways they offer (2b).

The 'nature of the difficulties experienced' code for identifying the predominant leadership model

Table 1 makes it clear that the difficulties that the participants most agree about are the variety and complexity of the job (i.e. internal in nature) and their relationship with the LEA (i.e. external in nature). If we look at the narratives classified under both codes in greater detail, we see that the principals stress the bureaucratic and administrative workload characteristic of the managerial leadership model (see Table 2, 3a and 3b), explicitly underlining that the weight of these tasks limits the time they can spend on pedagogical leadership. This code also shows the prevalence of the individual leadership style. This can be seen in narratives $1 \mathrm{a}$ and $1 \mathrm{~b}$ in Table 2 , which highlight the multiplicity of tasks that the principal carries out on an individual level and the latent content of the other narratives selected, which show that the figure of the principal is constantly spoken about without making any reference to the distribution of tasks.

The other code with the highest frequency percentage involves difficulties arising from relations with the LEA. These criticisms again lead us to think that the managerial leadership model predominates, since principals become intermediaries between the authorities and the schools and are given virtually no room for autonomy (Table 5, 4a and 4c), constrained as they are by lack of funding (Table 5, 1a), lack of support and the pressure to comply with the LEA's timelines (Table 5, 2b and 3a). Like in the previous case, these narratives do not point to the existence of a shared leadership model.

\section{Theme 2. Personal impact of the difficulties}

This theme gathers together information on two main aspects: (1) how the participants perceive their limitations in their role, and (2) the impact the leadership role has on their lives. Table 8 shows the descriptive data for these codes.

[Insert Table 8 about here] 


\subsection{Personal difficulties}

This category covers the narratives provided by participants that highlight the difficulties identified in the previous theme, but from a personal point of view.

\subsubsection{Personal weaknesses/limitations}

$52 \%$ of the interviewees (with a frequency percentage of $42 \%$ ) supplied data classified under this code, referring to the personal and professional constraints that hindered them in the proper performance of their leadership role. Since this code includes a broad spectrum of narratives, it has been broken down into three groups: (1) difficulties related to instrumental skills, (2) weaknesses associated with the leaders' personality traits, and (3) limitations in relationship and communication skills. Table 9 provides some examples.

\section{[Insert Table 9 about here]}

In some cases the participants point out that they lack training in certain aspects, which makes their job more difficult (example 1a). They also complain that they have to carry out administrative functions for which they are untrained, and this takes up time they could otherwise spend on pedagogical matters (1b). As for their personal limitations, they claim that their own personalities can be limiting in certain circumstances. Narrative 2a, for instance, shows that on occasion the principals feel that their own insecurity can become an obstacle. The same happens in narrative $2 \mathrm{~b}$, in which the interviewee admits that their impulsive character is a weakness. Finally, they also mentioned the communication problems they have noticed in their dealings with the rest of the education community (examples $3 a$ and $3 b)$.

\subsubsection{Life consequences}

About $59 \%$ of the participants (with a frequency percentage of 57.96\%) spoke of matters that fell within the scope of this code. They agreed that being principal has personal consequences because of the high demands placed on them, meaning more time spent away from their families. This sometimes results in a considerable psychological burden and increased levels of stress, which may even affect their physical well-being. An analysis of the information in this category gives us the following 
groups: (1) principalship seen as a demanding job, (2) the significant psychological burden, (3) appearance and aggravation of health problems, and (4) difficult work-family balance due to leadership role.

The narratives that illustrate these are shown in Table 10.

[Insert Table 10 about here]

Narrative 1a shows how working as a principal can become an obsession. These professionals spend hours of their free time working (example 1b), even though they are aware of the dangers this can entail (1c). They admit that the psychological load they carry and the suffering it may bring (2a) affects them on every level. As illustrated by narratives $2 b$ and $2 c$, it can interfere with their family life. Indeed there is not only a psychological impact but a physical one too. The interviewees reveal that they suffer from insomnia, nerves, exhaustion, stress, etc. ( $3 a$ and $3 b$ ). Naturally this situation spreads to home life. They miss out on time spent with their families, and this in turn has a very negative impact (4a and $4 b)$.

\section{Discussion and conclusions}

This section is divided into three subsections, each focusing on the area of one of the research questions.

Do the difficulties faced by the participating principals depend more on factors inherent to the leadership role or on external factors?

The data analysis shows that the participating principals made reference to both internal and external difficulties. They focused slightly more on those that inherently affect their leadership role, in particular stressing the number and variety of tasks associated with their position and the problems involved in leading the teaching staff. Most external difficulties, on the other hand, are highly localized and involve obstacles perceived as originating from the LEA.

The demands made of leaders in education have become more numerous and more complex over time, with their role extending to cover an ever-increasing number of tasks (Dinham, Anderson, Caldwelll and Welldon, 2011; Stringer and Blaik, 2015). Most of the participants criticized the 
excessive bureaucratic workload they have to deal with (De Jong et al., 2017), which prevents them from devoting time and effort to pedagogical leadership and generates professional dilemmas and high levels of frustration (Barrios-Arós et al., 2015; Markow et al., 2013). Leaders have been found to have a remarkable influence on teaching staff (Day et al., 2011). Several authors (Elmore, 2010; Timperley, 2008) have stressed the importance of the actions leaders take in fostering professional development opportunities. However, this is not without its difficulties. Such actions require structural changes that are not always feasible due to external limitations and restrictions.

The aspect that most affected principals and was mentioned most often in their discourses involved the LEA. While some authors (Bottery, Ngai, Wong and Wong, 2008; Thomson, 2008) have argued that the relevance of the limitations imposed by the LEA need to be considered in each particular context, some common ground is evident. This involves the limited autonomy of the leadership role, whether performed in centralized or decentralized contexts (Glatter, 2003). In centralized settings, responsibilities are transferred from central government to an intermediate authority, while in decentralized systems accountability processes are implemented to ensure that education leaders are made responsible for their actions through standards and rankings. In fact the principals' narratives concerning the restrictions imposed by, in this case, the LEA come across as acerbic, and the main reasons for this are budget cuts and downsizing. In the participants' view the LEA also hinders the development of innovative educational projects and programmes (Wells et al., 2011). Moreover, these school leaders feel that their work is undervalued and brings little financial reward (Owings, Kaplan and Chappell, 2011; Pont et al., 2008). Townsend (2011), for example, argues that there appears to be no difference between the working conditions of teachers and principals, when in fact the latter have a workload and responsibility that are notably different from those of a teacher. Principals have also said that they feel unprotected and are only listened to when faced with major problems, for which they do not always receive the support they need (Tucker, 2010). This gives rise to strong feelings of loneliness and isolation, as described in the study by Drago and Pecchia (2016).

While it is true that the participants in the present study had more to say about external difficulties, the combination of various internal and external factors leads us to conclude that there is a certain balance 
in the nature of the problems encountered. It could be said that, while there are certain factors that principals are unable to change, there are others that do fall within their scope. Their leadership experience as principals could perhaps be made more positive if these factors were identified and improved.

What experiences are associated with the participants' perception of the difficulties they have to deal with when carrying out their work?

Both the participating principals and the literature are in agreement that the principal's role comes at a very high personal cost. First of all, it carries a workload that encroaches into time spent with the family, as pointed out by Reames et al. (2014). The psychological and emotional burden of the role has been identified as an additional difficulty, which can even lead to health problems (Thomson, 2008; Tucker, 2010). The interviewees spoke of the considerable mental and physical exhaustion involved, which has also been noted by Lacey (2002). All the above aspects generate a certain level of disaffection with the role that translates into the post becoming increasingly difficult to fill (Harris and Jones, 2017, Reames et al., 2014) and keep filled (Campbell et al., 2014).

Of lesser importance, a tendency can also been seen among the participants to identify skills and capabilities in which they consider themselves deficient. The qualitative data indicate that these limitations apply to both instrumental skills (mastery of new technologies, good management and administration skills, a flair for pedagogical innovation, etc.) and personal skills (ability to communicate, persuade and coordinate the teaching staff, etc.). The interviewees also felt that their personal traits (insecurity, self-demands, impulsiveness, etc.) hindered their leadership performance. A final aspect mentioned in their narratives concerns the need to develop educational programmes to meet their current needs (Darling-Hammond, Meyerson, LaPointe and Terry, 2010). It is assumed that dealing with these aspects and overcoming personal limitations would help to alleviate the stress levels experienced (Boerema, 2011).

Overall this analysis allows us to see that, although the principals are self-critical in that they recognize their limitations, most problems arise as a result of the external and impersonal difficulties involved in leadership. 
What leadership models are characterized by the difficulties and weaknesses identified in the participants' discourses?

Given the variety of tasks that the participants mention, the emphasis on those relating to the burden of paperwork and the limitations associated with the LEA's management of the education system, it can be concluded that most principalships here follow the managerial leadership model (Bush and Glover, 2014). The narratives place the interviewees' management styles within the classic models of leadership. These are far removed from current trends, where the focus would be on shared leadership, attention to personal issues, improving the teaching and learning processes, etc. The difficulties encountered - especially those relating to the LEA — hamper the implementation of upto-date leadership models (distributed, systemic, learning-based, etc.), and this results in negative experiences. One might say that, although the participating principals do not personally identify with the managerial leadership model, they have no choice but to adopt it given the political constraints identified.

Finally, it would be useful to consider the guidelines for improving leadership given in an OECD study (Pont et al., 2008, p.9.), which recommends the following actions: make the role professionally appealing, redefine the responsibilities of leadership, develop skills for effective school leadership and apply models of shared leadership. If all these suggestions were implemented, many of the difficulties identified by the principals in this study could be remedied and the role made more attractive. We also believe that, in the Spanish context in particular, the gap needs to be closed between the scientific evidence, the legislation and the practice. Only then will it be possible to go beyond the managerial model and adopt models of shared leadership capable of responding to the new educational and social demands.

Continuing our work on this line of research would be interesting, since we could discover more about any possible correlation between the difficulties experienced and the predominant leadership model in the context studied. A more detailed analysis based on information from various sources (e.g. principals, inspectors and teachers) to enable triangulation would provide a wider view of the reality of the difficulties faced by principals in their work and recognition of how they affect leadership 
models. Using this recognition as a starting point, it would be easier to direct one's gaze and efforts towards the OECD guidelines on how to make the principal's job more attractive and contribute to changing a leadership model that survives in the context studied despite the fact that it strays far away from the parameters found in the literature, which are more suited to today's educational needs.

\section{References}

Aramendi, P., Teixidó, J., and Bernal, J.L. (2010). El acceso a la dirección escolar en los centros públicos del País Vasco. Revista Española de Pedagogía, LXVIII(246), 313-332. (In Spanish)

Barrios-Arós, C., Camarero-Figuerola, M., Tierno-García, JM., and Iranzo-García, P. (2015). Modelos y funciones de dirección escolar en España: El caso de Tarragona. Revista Iberoamericana de Educación, 67, 89-106. (In Spanish)

Barty, K., Thompson, P., Blackmore, J., and Sachs, J. (2005). Unpacking the issues: Researching the shortage of school principals in two states in Australia. Australian Educational Researcher, 32(3), $1-18$.

Bass, B., and Riggio, R. (2006). Transformational leadership. New York: Jossey-Bass.

Béteille, T., Kalogrides, D., and Loeb, S. (2011). Stepping stones: principal career paths and school outcomes. Cambridge: National Bureau of Economic Research.

Boerema, A.J. (2011). Challenging and supporting new leader development. Educational Management Administration \& Leadership, 39(5), 554-567. DOI: 10.1177/1741143211408451

Bolívar, A., López, J., and Murillo, F.J. (2013). Liderazgo en las instituciones educativas. Una revisión de líneas de investigación. Revista Fuentes, 14, 15-60. (In Spanish)

Bottery, M., Ngai, G., Wong, P.M., and Wong, P.H. (2008). Leaders and contexts: Comparing English and Hong Kong perceptions of educational challenges. International Studies in Educational Administration, 36(1), 56-71.

Bush, T. (2015). Aspiring to leadership: Facilitators and barriers. Educational Management Administration \& Leadership, 43(6), 855-860. DOI: 10.1177/1741143215597189

Bush, T., and Glover, D. (2014). School leadership models: What do we know? School Leadership \& Management, 34(5), 553-571. DOI: 10.1080/13632434.2014.928680 
Campbell, C., DeArmond, M., and Denice, P. (2014). School leadership in Washington State: Today's leaders and key challenges they face. Retrieved from University of Washington, Center for Reinventing Public Education: www.crpe.org

Cho, J.Y. and Lee, E. (2014). Reducing confusion about grounded theory and qualitative content analysis: Similarities and differences. The Qualitative Report, 19(32), 1-20.

Crawford, M. (2012). Solo and distributed leadership: definitions and dilemmas. Educational Management, Administration and Leadership, 40(5), 610-620. DOI: 10.1177/1741143212451175

Darling-Hammond, L., Meyerson, D., LaPointe, M., and Terry, M. (2010). Preparing Principals for a Changing World. Lessons from Effective School Leadership Programs. USA: Jossey-Bass.

Darmody, M., and Smyth, E. (2014). Primary school principals' job satisfaction and occupational stress. International Journal of Educational Management, 30(1), 115-128. DOI: 10.1108/IJEM-122014-0162.

Day, C., and Sammons, P. (2014). Successful school leadership. Retrieved from: https://www.educationdevelopmenttrust.com/ /media/EDT/Reports/Research/2015/r-successfulschool-leadership.pdf

Day, C., Sammons, P., Leithwood, K., Hopkins, D., Gu, Q., Brown, E., and Ahtaridou, E. (2011). Successful school leadership. Linking with learning and achievement. England: McGraw-Hill.

De Jong, D., Grundmeyer, T., and Yankey, J. (2017). Identifying and addressing themes of job dissatisfaction for secondary principals. School Leadership \& Management. DOI: $10.1080 / 13632434.2017 .1338253$

Dinham, S., Anderson, M., Caldwell, B, and Weldon, P. (2011). Breakthroughs in school leadership development in Australia. School Leadership \& Management: Formerly School Organisation, 31(2), 139-154. DOI: 10.1080/13632434.2011.560602

Döös, M., Wilhelmson, L., Madestam, J., and Örnberg, A. (2017). The shared principalship: invitation at the top. International Journal of Leadership in Education. DOI: $10.1080 / 13603124.2017 .1321785$

Doyle, D., and Locke, G. (2014). Lacking leaders: The challenges of principal recruitment, selection and placement. Washington: Thomas B. Fordham Institute. 
Drago, A., and Pecchia, V. (2016). From Isolation to Collaboration: School Principals. Ed.D. Capstone Projects. Paper 5. Retrieved from:

$\underline{\text { http://digitalcommons.tacoma.uw.edu/cgi/viewcontent.cgi?article }=1005 \& \text { context }=\text { edd_capstones }}$

Educational Research Service (2000). The Principal, Keystone of a High Achieving School: Attracting and Keeping the Leaders We Need. Arlington, VA: National Association of Elementary School Principals and National Association of Secondary School Principals.

Elmore, R.F. (2010). Mejorando la escuela desde la sala de clases. Santiago de Chile: Fundación Chile. (In Spanish)

Elo, S., and Kyngäs, H. (2007). The qualitative content analysis process. Journal of Advanced Nursing, 62(1), 107-115. DOI: 10.1111/j.1365-2648.2007.04569.x

Evans, A. (2009). No Child Left Behind and the Quest for Educational Equity: The Role of Teachers' Collective Sense of Efficacy. Leadership and Policy in Schools, 8(1), 64-91. DOI: $10.1080 / 15700760802416081$

General Act of Parliament (2013). Ley Orgánica 8/2013, de 9 de diciembre, para la mejora de la calidad educativa (General Law 8/2013 of 9 December on Improving Quality in Education). Boletín Oficial del Estado (Official State Bulletin), 10 December 2013. Retrieved from: http://www.edu.xunta.gal/centros/cpivianopequeno/system/files/LOMCE\%20Texto\%refundido\%2 0LOEpdf (In Spanish).

Glatter, R. (2003). Governance, autonomy and accountability. In M.Preedy, C. Wise and R.Glatter (Eds.), Strategic leadership and educational improvement (pp. 44-59). London: SAGE.

Goddard, J.T. (2003). Leadership in the (post) modern era. In N. Bennett and L. Anderson (Eds.), Rethinking educational leadership (pp. 11-26). London: SAGE.

Gu, Q., and Johansson, O. (2013). Sustaining school performance: School contexts matter. International Journal of Leadership in Education, 16(3), 301-316. DOI: $10.1080 / 13603124.2012 .732242$

Hallinger, P. (2016). Bringing context out of the shadows of leadership. Educational Management Administration \& Leadership. DOI: 10.1177/1741143216670652

Hallinger, P., and Heck, R.H. (2010). Leadership for learning: Does collaborative leadership make a 
difference in student learning? Educational Management Administration \& Leadership, 38(6), 654-678. DOI: $10.1177 / 1741143210379060$

Harris, A. (2013). Distributed leadership: Friend or foe? Educational Management Administration and Leadership, 41(5), 545-554. DOI: 10.1177/1741143213497635

Harris, A., and Jones, M. (2017). Leadership in turbulent times: a moment to pause? School Leadership \& Management, 37(1-2), 1-2. DOI: 10.1080/13632434.2017.1302043

Hesieh H. F., and Shannon, S. (2005). Three approaches to qualitative content analysis. Qualitative Health Research, 15(9), 1277-1288. DOI: 10.1177/1049732305276687

Hopkins, D., and Highman, R. (2007). System leadership: mapping the landscape. School leadership \& Management, 27(2), 147-166. DOI: 10.1080/13632430701237289

Huber, G.L., and Gürtler, L. (2013). AQUAD 7. Manual: The analysis of qualitative data. Tübingen, Germany: Authors. Retrieved from: http://www.aquad.de/materials/manual_aquad7/manual-e.pdf

Lacey, K.A. (2002). Understanding principal class leadership aspirations: Policy and planning implications. Melbourne: Right Angles Consulting Pty Ltd for Victoria Department of Education and Training. School Leadership Development Unit.

Lincoln, Y. S., and Guba, E. G. (1985). Naturalistic Inquiry. London, UK: SAGE.

MacBeath, J. (2011). No lack of principles: leadership development in England and Scotland. School Leadership and Management, 31(2), 105-121. DOI: 10.1080/13632434.2010.525029

Markow, D., Macia, L., and Lee, H. (2013). The Metlife survey of the American teacher. Challenges for School Leadership. New York: Metlife.

May, H., and Supovitz, J. (2011). The scope of principal efforts to improve instruction. Educational Administration Quarterly, 47(2), 332-352. DOI: 10.1177/0013161X10383411

Mehra, A., Smith, B. R., Dixon, A. L., and Robertson, B. (2006). Distributed leadership in teams: The network of leadership perceptions and team performance. Leadership Quarterly, 17(3), 232-245. DOI: 10.1016/j.leaqua.2006.02.003

Muijs, D., and Harris, A. (2007). Teacher Leadership in (In)action: Three Case Studies of Contrasting Schools. Educational Management, Administration \& Leadership, 35(1), 111-134. DOI:10.1177/1741143207071387 
Owings, W., Kaplan, L., and Chappell, S. (2011). Troops to Teachers as School Administrators. NASSP Bulletin, 95(3), 212-236. DOI:10.1177/0192636511415254.

Pearce, C. L., Manz, C. C., and Sims, H. P. (2008). The roles of vertical and shared leadership in the enactment of executive corruption: Implications for research and practice. Leadership Quarterly, 19(3), 353-359. DOI: 10.1016/j.leaqua.2008.03.007

Pont, B., Nusche, D., and Moorman, H. (2008). Improving School Leadership: policy and practice. Paris: OECD. Retrieved from: http://www.oecd.org/education/school/44374889.pdf

Reames, E.H., Kochan, F.K., and Zhu, L. (2014). Factors influencing principals' retirement decisions: a southern US perspective. Educational Management Administration \& Leadership, 42(1), 40-60.

Robinson, G. (2010). Leading Change in Multiple Contexts: Concepts and Practices in Organizational, Community, Political, Social, and Global Change Settings. London: SAGE.

Robinson, V.M.J., Lloyd, C.A., and Rowe, K.J. (2008). The impact of leadership on student outcomes: An analysis of the differential effects of leadership types. Educational Administration Quarterly, 44, 635-674. DOI: 10.1177/0013161X08321509

Rodríguez, C., García, F., García, I., and Álvarez, J. (2013). La problemática de la función directiva en primaria desde posiciones encontradas. Los directores frente al profesorado. Profesorado. Revista de Currículum y Formación del Profesorado, 17(2), 421-440. (in Spanish)

Schechter, Ch., Shaked, H., Ganon-Shilon, S., and Goldratt, M. (2016). Leadership metaphors: School principals' sense-making of a National Reform. Leadership \& Policy in Schools. DOI: $10.1080 / 15700763.2016 .1232836$

Stringer, P., and Blaik, H. (2015). Transformation of roles and responsibilities of principals in times of change. Educational Management Administration \& Leadership, 1-23. DOI: $10.1177 / 1741143214549971$

Thomson, P. (2008). Answering back to policy? Headteachers' stress and the logic of the sympathetic interview. Journal of Education Policy, 23(6), 649-667. DOI: 10.1080/02680930802214248

Timperley, H. (2008). Teacher professional learning and development. Brussels: International Academy of Education (IAE). 
Townsend, T. (2011). School leadership in the twenty-first century: different approaches to common problems? School Leadership and Management, 31(2), 93-103. DOI: $10.1080 / 13632434.2011 .572419$

Tucker, S. (2010). An investigation of the stresses, pressures, and challenges faced by primary school headteachers in context of organizational change in schools. Journal of Social Work Practice, 24(1), 63-74. DOI: 10.1080/02650530903532765

Ulhøi, J.P., and Müller, S. (2014). Mapping the landscape of shared leadership: A review and synthesis. International Journal of Leadership Studies, 8(2), 66-87.

Wahlstrom, K., Louis, K., Leithwood, K., and Anderson, S. (2010). Investigating the links to improved student learning. New York: The Wallace Foundation.

Weindling, D., and Dimmock, C. (2006). Sitting in the "hot seat": new headteachers in the UK. Journal of Educational Administration, 44(4), 326-340. DOI: 10.1108/09578230610674949

Wells, C. M., Maxfield, C.R., and Klocko, B. (2011). Complexities Inherent in the Workload of Principals: Implications for Teacher Leadership. In Alfrod, B.J. (Ed.), Blazing new trails: Preparing leaders to improve access and equity in today's schools (pp. 29-46). Lancaster, PA: ProActive Publications.

Wilhelmson, L., and Döös, M. (2016b). Joint principalship: A potential support for democratic practice in schools. Nordic Journal of Studies in Educational Policy, 2(1), 1-11. DOI:10.3402/nstep.v2.31681

Wohlstetter, P., Datnow, A., and Park, V. (2008). Creating a system for data-driven decision making: Applying the principal-agent framework. School Effectiveness and School Improvement, 19(3), 239-259.

Yukl, G. (2006). Leadership in Organizations. Paramus: Prentice Hall 